\title{
Age-related macular degeneration with choroidal neovascularization in the setting of pre-existing geographic atrophy and ranibizumab treatment. Analysis of a case series and revision paper*
}

\author{
Avaliação da resposta da injeção intravitrea de ranibizumab em \\ pacientes com neovascularização de coróide da degeneração \\ macular relacionada à idade com atrofia geográfica \\ extensa pré-existente e revisão da literatura
}

\begin{abstract}
Purpose: To report the response of choroidal neovascularization $(C N V)$ to intravitreal ranibizumab treatment in the setting of agerelated macular degeneration (AMD) with extensive pre-existing geographic atrophy (GA) and a revision paper. Methods: This is a revision paper and a retrospective case series of 10 eyes in nine consecutive patients from a photographic database. The patients were actively treated with ranibizumab for neovascular AMD with extensive pre-existing GA. Patients were included if they had GA at or adjacent to the foveal center that was present before the development of CNV. The best corrected visual acuity and optical coherence tomography (OCT) analysis of the central macular thickness were recorded for each visit. Serial injections of ranibizumab were administered until there was resolution of any subretinal fluid clinically or on OCT. Data over the entire follow-up period were analyzed for overall visual and OCT changes. All patients had been followed for at least 2 years since diagnosis. Results: The patients received an average of $6 \pm 3$ intravitreal injections over the treatment period. Eight eyes had reduced retinal thickening on OCT. On average, the central macular thickness was reduced by $94 \pm 101 \mu \mathrm{m}$. Eight eyes had improvement of one or more lines of vision, whereas one eye had dramatic vision loss and one had no change. The average treatment outcome for all patients was $-0.07 \pm 4.25 \log M A R$ units, which corresponded to a gain of $0.6 \pm 4.4$ lines of Snellen acuity. The treatment resulted in a good anatomic response with the disappearance of the subretinal fluid, improved visual acuity, and stabilized final visual results. Conclusion: The results of this case series suggest that the use of an intravitreal anti-vascular endothelial growth factor (VEGF) agent (ranibizumab) for CNV in AMD with extensive pre-existing GA is effective. Our results are not as striking as published results from large-scale trials of anti-VEGF therapy for subfoveal CNV, presumably due to the limitation in the baseline visual acuity caused by the underlying GA. The good anatomic response with the disappearance of the subretinal fluid, improved visual acuity, and stabilized final visual results were consistent with other ranibizumab studies.
\end{abstract}

Keywords: Macular degeneration; Geographic atrophy; Choroidal neovascularization; Antibodies, monoclonal/therapeutic use; Retina

\footnotetext{
${ }^{1}$ Instituto de Olhos e Laser de Belém. Belém (PA), Brazil. Doctorate by the Federal University of São Paulo, Brazil;

2 Retina Service, lowa University, USA.

*Study carried out at Retina Service, University of lowa and Instituto de Olhos e Laser de Belém. Belém (PA), Brazil
}

The authors declare no conflicts of interest

Recebido para publicação em: 9/1/2012 - Aceito para publicação em: 2/3/2012 


\section{RESUMO}

Investigar os resultados da injeção intravítrea de Ranibizumab em pacientes com neovascularização de coróide da degeneração macular relacionada a idade, com atrofia geográfica extensa, pré-existente e revisão da literatura. Métodos: Este é um artigo de revisão e também um estudo retrospectivo de 9 pacientes, 10 olhos com neovascularização de coróide da degeneração macular relacionada à idade, com atrofia geográfica extensa, pré-existente. Os pacientes incluídos apresentaram atrofia geográfica, envolvendo a fóvea ou adjacente, antes do desenvolvimento da neovascularização de coróide. A melhor correção visual e o exame de tomografia de coerência óptica (OCT) com analise da espessura macular foram registrados em cada visita. As injeções de ranibizumab intravítrea foram feitas até a resolução do líquido sub-retiniano pelo OCT e clinicamente. Todos os pacientes tinham seguimento de 6 meses do diagnostico a 2 anos, com média de 16 meses. Resultados: 10 olhos de 9 pacientes incluídos receberam uma média de $6 \pm$ 3 injeções intravítreas de ranibizumab, sendo que 8 apresentaram redução do espessamento macular pelo OCT. A mácula teve o espessamento reduzido entre $94 \pm 101$ microns, 8 olhos tiveram melhora de 1 ou mais linhas de visão, um olho teve acentuada diminuição da visão.e um outro não teve alteração. A media do resultado do tratamento em $\log$ MAR era $-0,07 \pm 4.25$ correlacionando um ganho de visão na tabela de Snellen entre 0,6 6 4.4linhas de visão. Conclusão: Estes resultados sugerem que o uso do Ranibizumab intravítreo para neovascularização de coróide da degeneração macular relacionada à idade em extensa atrofia geográfica préexistente é efetivo. Existem, entretanto, dificuldades na avaliação da acuidade visual destes pacientes em virtude da extensa Atrofia Geográfica que apresentavam e sobre esta ainda as complicações da neovascularização de coróide, se comparados a casos em que a neovascularização de coróide não ocorre em atrofia geográfica pré-existente.

Descritores: Degeneração macular; Atrofia geográfica; Neovascularização de coróide; Anticorpos monoclonais/uso terapêutico; Retina

\section{INTRODUCTION}

$\mathbf{G}$ eographic atrophy (GA) is defined in the AREDS study as one or more well-defined, usually more or less circu lar, patches of partial or complete depigmentation of the retinal pigment epithelium (RPE), typically with exposure of underlying large choroidal blood vessels ${ }^{(1)}$. GA associated with age-related macular degeneration (AMD) is estimated to affect nearly $1 \%$ of the US population, with this prevalence expected to increase by $50 \%$ by the year $2020^{(2)}$. GA is a form of advanced age-related macular degeneration (AMD) that causes central visual loss and evolves gradually in the central fovea ${ }^{(1)}$.

Histopathological sections of GA show thinning or absence of the RPE, closure of the choriocapillaris, and degeneration of the overlying photoreceptors ${ }^{(3,4)}$. It has been reported ${ }^{(3,4)}$ that the site of the initial appearance of GA was previously occupied by drusen, which was large (125 ì $\mathrm{m}$ in diameter) in $96 \%$ of cases. In $83 \%$ of eyes, the largest drusen was $250 \mathrm{ì} \mathrm{m}$ in diameter. The drusen was usually confluent, with at least two in contact, but it is sometimes extensive enough to form plaques of drusenoid material. In addition, the GA is nearly always preceded by the appearance of hyperpigmentation overlying drusen, followed by regression of the drusen and the appearance of hypopigmentation, sometimes accompanied by refractile deposits. Furthermore, in some eyes, different precursor lesions might appear simultaneously. Research ${ }^{(5,6)}$ has shown that the strongest predictor of the subsequent spread of GA is growth in the previous 2 years. Increased fundus autofluorescence outside atrophic patches of GA may also be an important predictor of subsequent progression ${ }^{(7)}$.

Another finding in advanced AMD is choroidal neovascularization $(\mathrm{CNV})^{(8)}$. Although hyperpigmentation and hypopigmentation abnormalities of the RPE and drusen are precursors of GA and $\mathrm{CNV}$, these are related only because they are advanced forms of age-related macular degeneration ${ }^{(8,9)}$.

The coexistence of GA and CNV has been proved histopathologically ${ }^{(3,4,10)}$. Some studies ${ }^{(11,12)}$ have shown that the vascular endothelial growth factor (VEGF)-specific monoclonal antibodies, ranibizumab and bevacizumab, improve the visual acuity in patients with AMD and subfoveal CNV ${ }^{(11,14)}$. In the Marina $^{(11)}$ and Anchor ${ }^{(12)}$ trials with ranibizumab, $94.6 \%$ and $96.4 \%$ of the patients avoided a 15-letter VA decrease, respectively. Moreover, $34 \%$ and $43 \%$ of patients gained at least 15 letters of VA, respectively. The final mean improved by 7.2 and 11.3 letters in the Marina ${ }^{(11)}$ and Anchor ${ }^{(12)}$ trials, respectively. However, other treatments have been used, including laser photocoagulation ${ }^{(15,16)}$, verteporfin photodynamic therapy $(\mathrm{PDT})^{(17)}$, photothrombosis with indocyanine green ${ }^{(18)}$, and pegaptanib sodium intravitreal injection ${ }^{(19)}$.

This report is a revision paper and investigated the results of ranibizumab intravitreal monotherapy in the treatment of $\mathrm{CNV}$ in the context of AMD with extensive pre-existing GA.

\section{Methods}

This is a revision paper and a retrospective cases series study from a photographic database center of 10 eyes in 9 consecutive patients under active treatment with ranibizumab monotherapy for neovascular AMD in the setting of pre-existent Geographic Atrophy. Patients were included if they had GA at or adjacent to the central fovea that was present before the development of CNV (Figures 1 to 7). The exclusion criterion was no prior treatment of CNV from AMD with extensive pre-existing GA only permissible in the AREDS formulation ${ }^{(20)}$. The best corrected visual $\log$ MAR and Snellen schedule, color fundus photography, fluorescein angiography, and optical coherence tomography (OCT) were obtained each visit. We used Heidelberg OCT to analyze the central macular thickness, which we recorded each month. Ranibizumab monotherapy was injected intravitreal monthly until there was resolution of the subretinal fluid clinically or by OCT (criteria of retreatment) for a 2-year period. Data on the overall visual and OCT changes over the entire follow-up 2year period were analyzed. All patients were followed for at least 6 months (mean 16 months) and up to 2 years after diagnosis.

\section{Results}

The study included 10 eyes from 9 patients who had been treated with ranibizumab as monotherapy. The patients received an average of $6 \pm 3$ intravitreal injections over the treatment period. Eight eyes had reduced retinal thickening on OCT. On average, the central macular thickness was reduced by $94 \pm 101$ $\mu \mathrm{m}$. Eight eyes had an improvement of one or more lines of vision, whereas one eye had dramatic vision loss and one eye hasn't change in his vision. The average treatment outcome for all patients was $-0.07 \pm 4.25 \log$ MAR units, which corresponded to a gain of $0.6 \pm 4.4$ lines of Snellen acuity. 

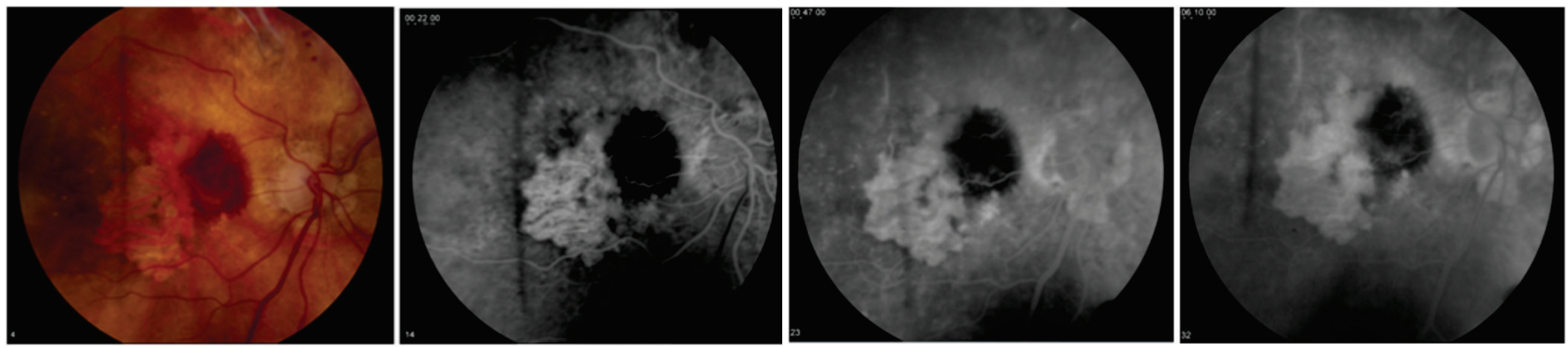

Figure 1: Choroidal hemorrhage from occult CNV in geographic atrophy, patient number 6
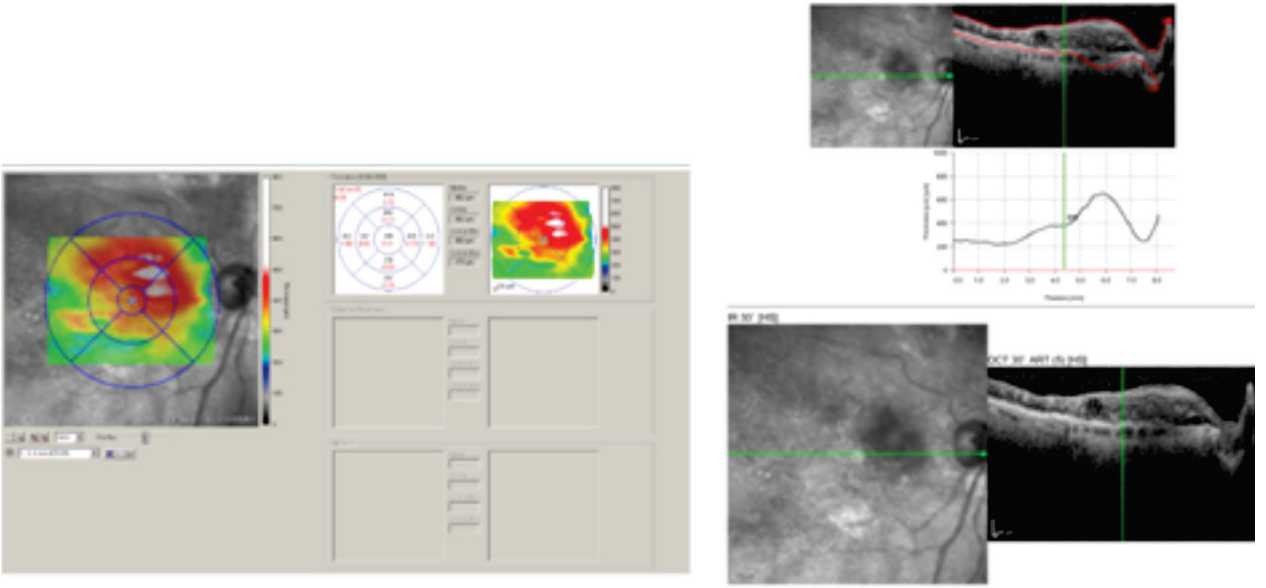

Figure 2: Patient number 6: OCT before treatment showing thinning along the temporal aspect of the central macula, and some diffuse thickening as well as some cystoid abnormalities around the nasal aspect of the central macula
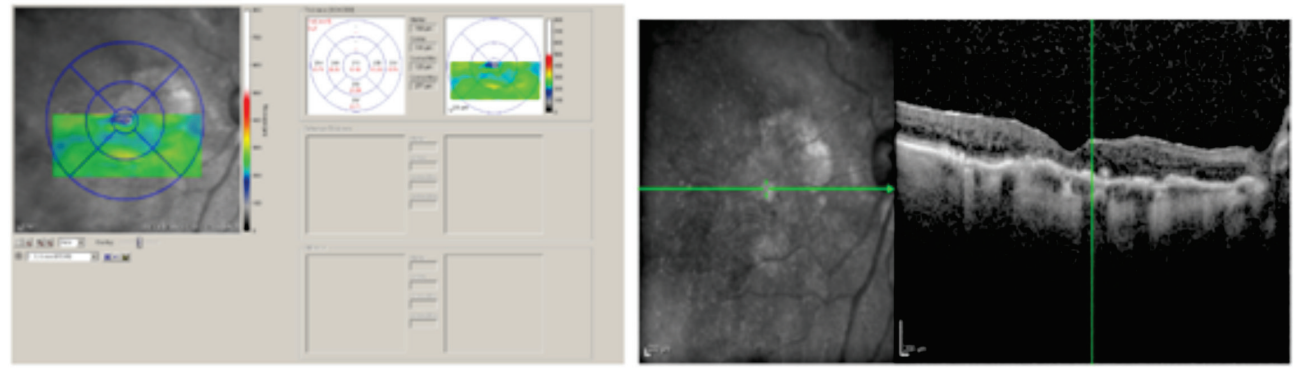

Figure 3: OCT after treatment showing resolution of findings

Choroidal neovascularization and GA are advanced forms of AMD according the AREDS reports ${ }^{(1)}$ and others ${ }^{(8,10)}$. When CNV develops in eyes with GA, it can cause both an abrupt drop in visual acuity and progression to central vision loss. ${ }^{8,10}$ The AREDS data ${ }^{(2)}$ indicate that about one-third of the participants had central GA at the time when GA was first identified, there was a median time to progression from GA to central GA of 2 years. Visual acuity is often decreased before the development of central GA; for those who do not develop CNV, vision is expected to decline an additional 22 letters on average during the next 5 years. Eyes that develop subsequent CNV have an even worse prognosis.

The reported 2 -year rate of $18 \%$ and 4 -year rate of $34 \%$ of $\mathrm{CNV}$ in eyes with GA is compatible with the MPS study ${ }^{(15)}$ and that of Sunness et al. ${ }^{(10)}$ Other studies ${ }^{(21,23)}$ reported similar rates of CNV developing in eyes with GA. This is a high incidence and disproves the impression that GA protects against the development of CNV. In a study of the treatment of extrafoveal $\mathrm{CNV}$ from AMD, the MPS ${ }^{(15)}$ included 11 participants with GA and without $\mathrm{CNV}$ in the fellow eye at baseline. Over a 5-year period, five $(45 \%)$ patients went on to develop CNV in the GA eye. The MPS report included participants from the juxtafoveal and subfoveal AMD trials.

In a case report on a patient with $\mathrm{GA}^{(3)}$, with clinicopathological evaluation, in whom the existence of $\mathrm{CNV}$ was not initially suspected and a fluorescein angiogram had not revealed $\mathrm{CNV}$, the researchers noted that $\mathrm{CNV}$ developed in one eye with GA in areas of residual choriocapillaris and pigment epithelium, while no CNV developed in the fellow eye with GA despite breaks in Bruch's membrane, presumably because the breaks occurred in areas without residual choriocapillaris and RPE, similar to the study by Sunness et al. ${ }^{(10)}$ Similar to our study, CNV did not grow over atrophy and was seen to develop at the edge of the GA (Yannuzzi L, personal communication) or in spared areas within the GA.

In our study, eight eyes had improvement of one or more lines of vision, whereas one eye had dramatic vision loss and one 


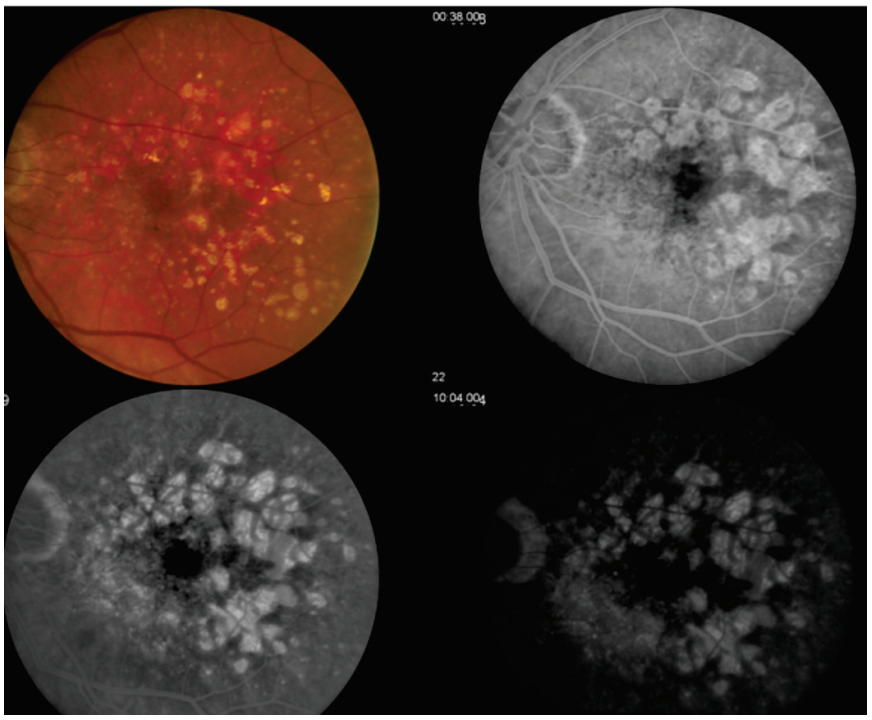

Figure 4: Extensive geographic atrophy, patient number 7

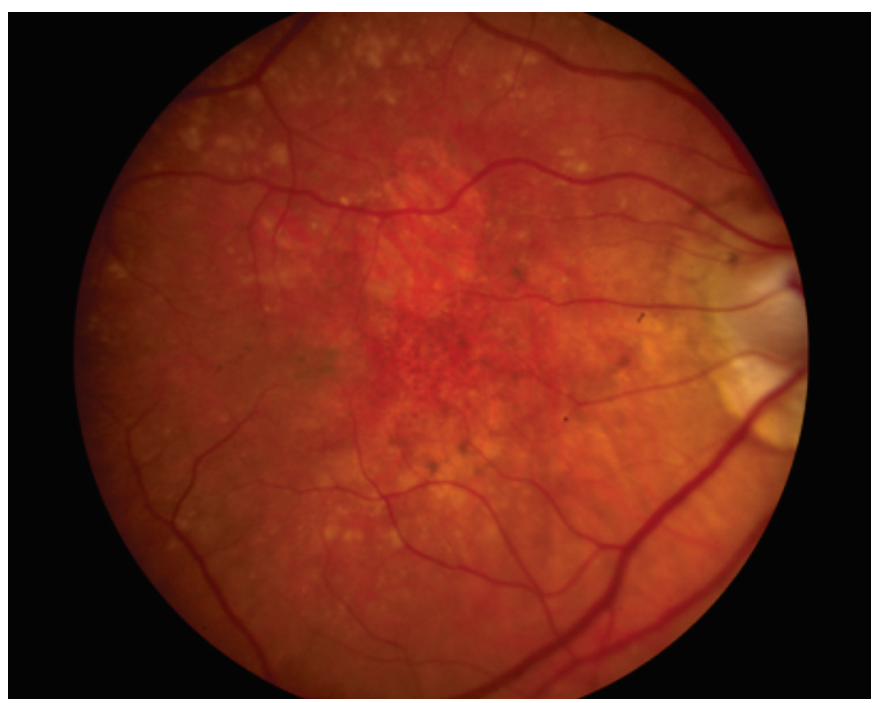

Figure 6: Extensive geographic atrophy, patient number 9

had no change.

The patients received an average of $6 \pm 3$ intravitreal injections over the treatment period. Most of them ( 8 out 9 patients) had reduced retinal thickening on OCT. On average, the central macular thickness was reduced by $93 \pm 105 \mu \mathrm{m}$. The average treatment outcome for all patients was $-0.07 \pm 4.25$ $\operatorname{logMAR}$ units, which corresponded to a gain of $0.6 \pm 4.4$ lines of Snellen acuity.

The Marina ${ }^{(11)}$ and Anchor ${ }^{(12)}$ studies proved the efficacy of anti-VEGF therapy with ranibizumab in the treatment of subfoveal CNV. Eight of our 10 patients improved their vision with ranibizumab treatment for $\mathrm{CNV}$ in AMD with extensive pre-existing GA and reports of ranibizumab treatment of choroidal neovascularization in the setting of pre-existing Geographic Atrophy from AMD ${ }^{(24,25)}$ with similar results as: good anatomic response with disappearance of the subretinal fluid, improved visual acuity and stabilized final visual results consistent with others ranibizumab studies ${ }^{(11,12,24,25)}$.

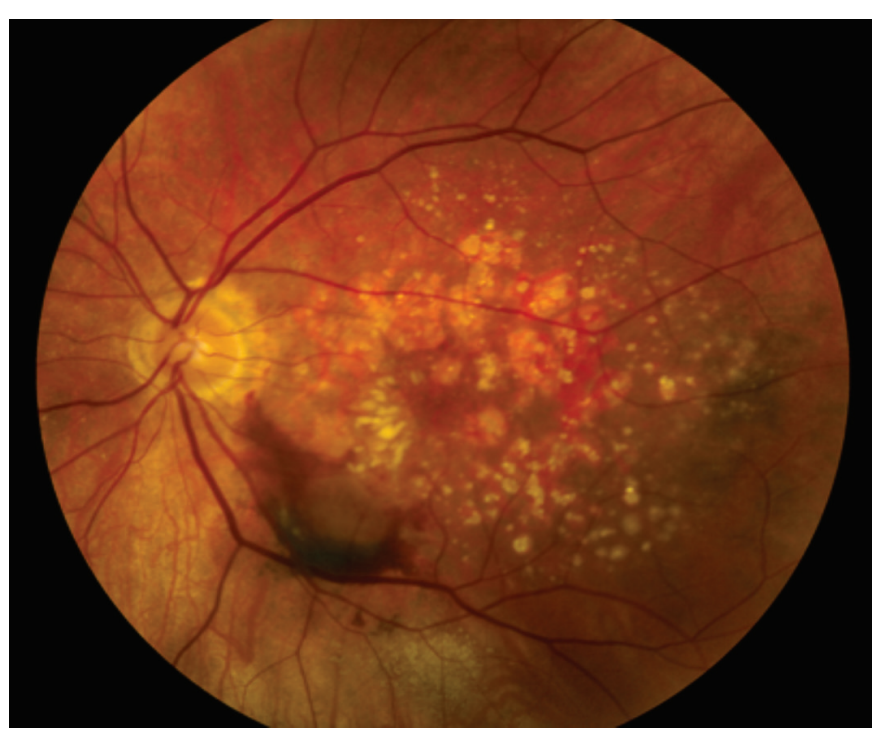

Figure 5: Choroidal hemorrhage from occult $\mathrm{CNV}$ in geographic atrophy, patient number 7
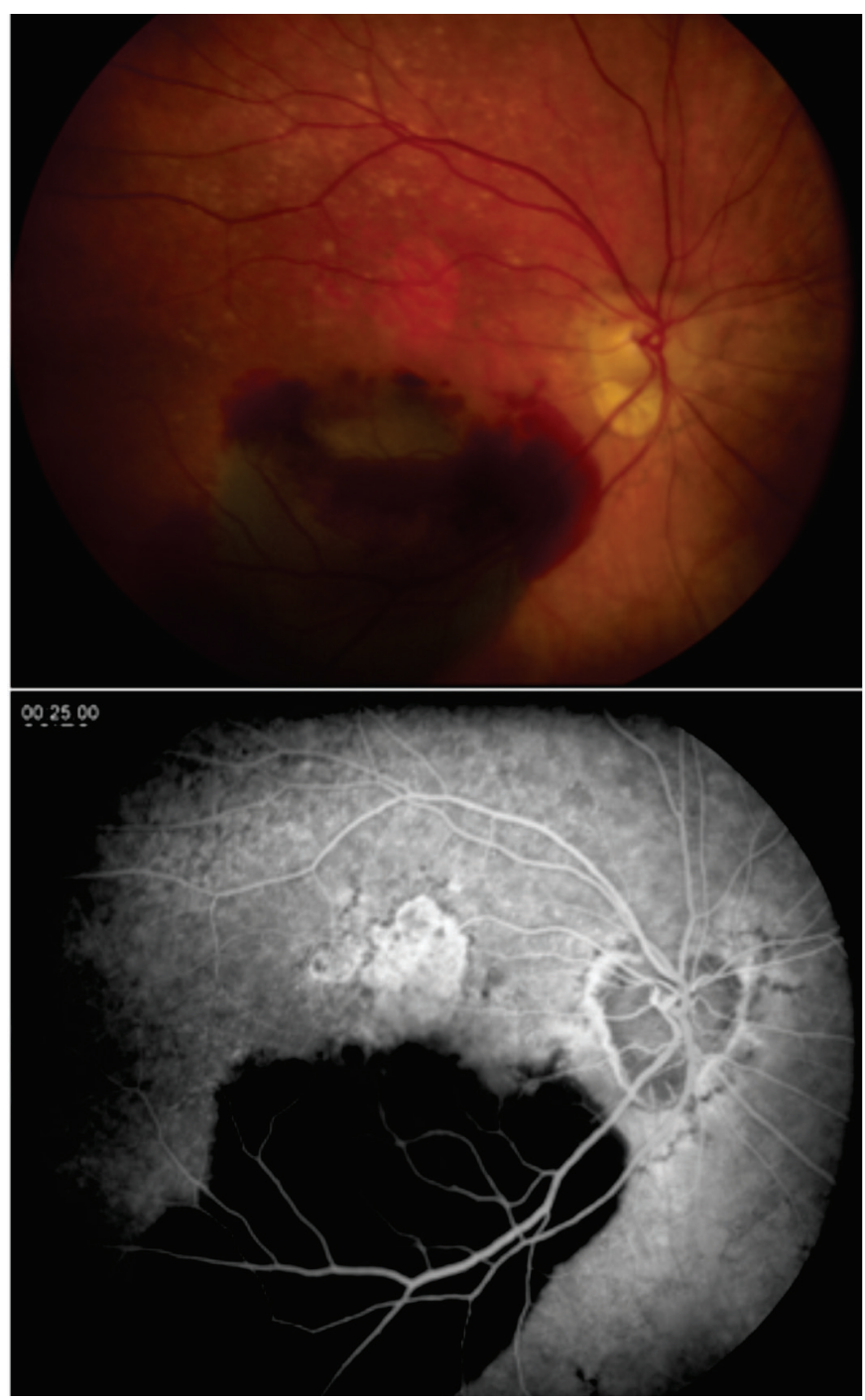

Figure 7: Choroidal hemorrhage from occult $\mathrm{CNV}$ in geographic atrophy, patient number 9 


\section{Conclusion}

The results of this cases series suggest that the use of an intravitreal anti-VEGF agent (ranibizumab) for CNV in AMD with extensive pre-existing GA is effective for these patients. Our results are not as striking as the results of large-scale trials of anti-VEGF therapy for subfoveal CNV, presumably due to the limitation of the baseline visual acuity caused by the underlying GA.

\section{RefERENCES}

1. Lindblad AS, Lloyd PC, Clemons TE, Gensler GR, Ferris FL 3rd, Klein ML, Armstrong JR; Age-Related Eye Disease Study Research Group. Change in area of geographic atrophy in the AgeRelated Eye Disease Study: AREDS report number 26. Arch Ophthalmol. 2009;127(9):1168-74.

2. Friedman DS, O'Colmain BJ, Muñoz B, Tomany SC, McCarty C, de Jong PT, Nemesure B, Mitchell P, Kempen J; Eye Diseases Prevalence Research Group. Prevalence of age-related macular degeneration in the United States. Arch Ophthalmol. 2004;122(4): 564-72. Erratum in: Arch Ophthalmol. 2011;129(9):1188

3. Green WR, Key SN 3rd. Senile macular degeneration: a histopathologic study. Trans Am Ophthalmol Soc. 1977;75:180-254.

4. Green WR, Enger C. Age-related macular degeneration histopathologic studies. The 1992 Lorenz E. Zimmerman Lecture. Ophthalmology. 1993;100(10):1519-35.

5. Sunness JS, Margalit E, Srikumaran D, Applegate CA, Tian Y, Perry D, et al. The long-term natural history of geographic atrophy from age-related macular degeneration: enlargement of atrophy and implications for interventional clinical trials. Ophthalmology. 2007;114(2):271-7.

6. Sunness JS, Applegate CA, Bressler NM, Hawkins BS. Designing clinical trials for age-related geographic atrophy of the macula: enrollment data from the geographic atrophy natural history study. Retina. 2007;27(2):204-10.

7. Holz FG, Bindewald-Wittich A, Fleckenstein M, Dreyhaupt J, Scholl HP, Schmitz-Valckenberg S; FAM-Study Group. Progression of geographic atrophy and impact on fundus autofluorescence patterns in age-related macular degeneration. Am J Ophthalmol. 2007;143(3):463-72.

8. Gass JD. Steroscopic atlas of macular diseases: diagnosis and treatment. 4th ed. St Louis: Mosby; 1997. p. 70-86.

9. Gass JD. Drusen and disciform macular detachment and degeneration. Arch Ophthalmol. 1973;90(3):206-17.

10. Sunness JS, Gonzalez-Baron J, Bressler NM, Hawkins B, Applegate CA. The development of choroidal neovascularization in eyes with geographic atrophy form of age-related macular degeneration. Ophthalmology. 1999;106(5):910-9.

11. Rosenfeld PJ, Brown DM, Heier JS, Boyer DS, Kaiser PK, Chung CY, Km RY; MARINA Study Group. Ranibizumab for neovascular age-related macular degeneration. N Engl J Med. 2006;355(14): 1419-31.

12. Brown DM, Kaiser PK, Michels M, Soubrane G, Heier JS, Kim RY, Sy JP, Schneider S; ANCHOR Study Group. Ranibizumab versus verteporfin for neovascular age-related macular degeneration. N Engl J Med. 2006;355(14):1432-44. Comment in N Engl J Med. 2006;355(14):1409-12. N Engl J Med. 2007;356(7): 748-9; author reply 749-50. N Engl J Med. 2007;356(7):747-8; author reply 749-50. N Engl J Med. 2006;355(14):1493-5.

13. Rich RM, Rosenfeld PJ, Puliafito CA, Dubovy SR, Davis JL, Flynn HW Jr, et al. Short-term safety and efficacy of intravitreal bevacizumab (Avastin) for neovascular age-related macular degeneration. Retina. 2006;26(5):495-511.
14. Rosenfeld PJ, Moshfeghi AA, Puliafito CA. Optical coherence tomography findings after an intravitreal injection of bevacizumab (avastin) for neovascular age-related macular degeneration. Ophthalmic Surg Lasers Imaging. 2005;36(4):331-5. Comment in Ophthalmic Surg Lasers Imaging. 2005;36(4):270-1.

15. Five-year follow-up of fellow eyes of patients with age-related macular degeneration and unilateral extrafoveal choroidal neovascularization. Macular Photocoagulation Study Group. Arch Ophthalmol. 1993;111(9):1189-99. Comment in Arch Ophthalmol. 1994;112(7):874-5.

16. Subfoveal neovascular lesions in age-related macular degeneration. Guidalines for evaluation and treatment in the macular photocoagulation study. Macular Photocoagulation Study Group. Arch Ophthalmol. 1991;109(9):1242-57. Comment in Arch Ophthalmol. 1991;109(9):1217-8.

17. Miller JW, Schmidt-Erfurth U, Sickenberg M, Pournaras CJ, Laqua $\mathrm{H}$, Barbazetto I, et al. Photodynamic therapy with verteporfin for choroidal neovascularization caused by age-related macular degeneration: results of a single treatment in a phase 1 and 2 study. Arch Ophthalmol. 1999;117(9):1161-73. Erratum in Arch Ophthalmol 2000;118(4): 488. Comment in Arch Ophthalmol. 1999;117(9):117787. Comment on Arch Ophthalmol. 1999;117(9):1177-87.

18. Cardillo JA, Jorge R, Costa RA, Nunes SM, Lavinsky D, Kuppermann BD, et al. Experimental selective choriocapillaris photothrombosis using a modified indocyanine green formulation. Br J Ophthalmol. 2008;92(2):276-80.

19. Gragoudas ES, Adamis AP, Cunningham ET Jr, Feinsod M, Guyer DR; VEGF Inhibition Study in Ocular Neovascularization Clinical Trial Group. Pegaptanib for neovascular age-related macular degeneration. N Engl J Med. 2004;351(27):2805-16. Comment in ACP J Club. 2005;143(1):18. N Engl J Med. 2005;352(16):17201; author reply 1720-1. N Engl J Med. 2004;351(27):2863-5.

20. Age-Related Eye Disease Study Research Group. A randomized, placebo-controlled, clinical trial of high-dose supplementation with vitamins $\mathrm{C}$ and $\mathrm{E}$, beta carotene, and zinc for age-related macular degeneration and vision loss: AREDS report no. 8. Arch Ophthalmol. 2001;119(10):1417-36. Erratum in Arch Ophthalmol. 2008;126(9):1251. Comment in Arch Ophthalmol. 2002;120(1): 100-1. Arch Ophthalmol. 2001;119(10):1533-4. JAMA. 2001; 286(19): 2466-8. Arch Ophthalmol. 2003;121(3):416-7. J Fam Pract. 2002;51(2):105. Arch Ophthalmol. 2008;126(1):146-7; author reply 147. Arch Ophthalmol. 2002;120(7):997; author reply 997-9. Arch Ophthalmol. 2002;120(11):1602.

21. Sarks JP, Sarks SH, Hillingsworth MC. Evolution of geographic atrophy of the retinal pigment epithelium. Eye (Lond). 1988;2 (Pt5):552-77.

22. Schatz H, McDonald HR. Atrophic macular degeneration. Rate of spread of geographic atrophy and visual loss. Ophthalmology. 1989;96(10):1541-51.

23. Sunness JS, Bressler NM, Maguire MG. Scanning laser ophthalmoscopic analysis of the pattern of visual loss in age-related geographic atrophy of the macula. Am J Ophthalmol. 1995;119(2): 143-51

24. Amaro $\mathrm{MH}$, Roller $\mathrm{AB}$. Intravitreal ranibizumab therapy for choroidal neovascularization in age-related macular degeneration with extensive pre-existing geographic atrophy [abstract]. Invest Ophthalmol Vis Sci. 2011;52:E-Abstract 4004.

25. Roller $\mathrm{AB}, \mathrm{Amaro} \mathrm{MH}$. Intravitreal ranibizumab and bevacizumab therapy for choroidal neovascularization in age-related macular degeneration with extensive geographic atrophy. In press 2012.

\section{Autor correspondente:}

Miguel Hage Amaro,MD

Trav. Quintino Bocaiúva, no 516

CEP 66053- 240 - Belém - (PA), Brasil

Tel: (91) 3223.6741 / (91) 3242-7067

E-mail: miguelhamaro@yahoo.com.br amaro@amazon.com.br 